John M. Stienen

Independent Researcher

https://doi.org/10.18485/bgd_nlistiek_30.2018.ch16

\title{
CAPTIVITY AND DEATH AMONG THE SERBIAN PRISONERS OF WAR WHO PASSED THROUGH THE NETHERLANDS DURING THE GREAT WAR
}

\begin{abstract}
Following the battles between Serbia and the Central Powers in 1914 and 1915, tens of thousands of Serbian servicemen ended up in Austro-Hungarian, Bulgarian, German and Ottoman captivity. Nearly 30,000 Serbian soldiers and just a handful of officers joined the almost 2,000,000 prisoners of war of the other Entente countries in camps throughout the German Empire. According to contemporary sources 637 Serbian prisoners of war escaped from those camps and almost 2000 died there. Their mortality rate was higher than the average of the other nationalities. After the armistice in 1918 some of these Serbians were repatriated via Dutch ports. Most of these men arrived there by ship over the Rhine. After going through various locations, sometimes transit camps, they departed via Rotterdam or Vlissingen towards France. Due to the winter weather conditions and epidemics some of the men died en route - on neutral Dutch soil. Again, the death rate among Serbians was higher than the average among the other Entente servicemen. This article examines the similarities and differences between the fate of the Serbians and servicemen of other nationalities in Central Power captivity during the Great War and seeks to find plausible explanations for the differences in mortality found for those held captive in Germany and Austria-Hungary.
\end{abstract}

Keywords: World War One; Serbian army; ex-prisoners of war; escaped prisoners of war; repatriation.

\section{Introduction}

The last decades have seen the emergence of many publications regarding the fate of prisoners of war during the Great War. Not surprisingly, given their vast numbers and the fact that the Russian archives were opened in the 1990s, the Eastern front and the Russian prisoners received much attention. The disappearance of the 'Tsar and Fatherland' they fought for may have been the reason these prisoners had been almost entirely missing from the post-World War I literature. That literature was dominated by experiences of French, British and German prisoners of war, and there was a general disinterest in what happened to those from other countries. (Rachamimov 2002: 222228). ${ }^{1}$

1 Note the scarce other examples. (Otto 2008 and Weiland 1931). 
Like their Russian allies, also the Serbian prisoners of war were missing from the postwar narrative - in spite of them being among the first to be held captive in the long hot summer of 1914. Early research includes work by Mitrović and Stojančević, who - more than thirty years after their ground-breaking research - still set the tone for others who publish about Serbian prisoners of war between 1914 and 1918. In more recent years the topic has received more attention, notably by Serbian scholars such as Bjelajac, Denda, Ilić-Marković, Lukić, Ristić, and Vemić. Recently Radovanović published a study on the Serbian section of a Dutch relief society based on contemporary postal stationery.

\section{Captivity and mortality}

As most authors who deal with the subject discover sooner or later, obtaining reliable statistics on Entente prisoners of war in Central Power captivity is a particular challenge. Most of the published figures were compiled in the interwar period for different - including revisionist - purposes. The problem is that captor states tend to publish lower numbers, while the states the captives came from often overstate the numbers, for example in their claims at the 1919 Paris Peace Conference.

On 21 August 1914, three and a half weeks after the start of hostilities, the International Prisoners of War Agency (IPWA) opened in Geneva, as part of the International Committee of the Red Cross (ICRC). Its role was to restore contact between people separated by the war - prisoners of war, civilian internees and civilians in occupied territories. In this capacity the agency would serve as means of communication between belligerents regarding enemy prisoners of war in their custody.

Under Article 14 of the Regulations annexed to the Hague Convention respecting the Laws and Customs of War on Land of 1907 ('the Regulations') each belligerent state was required to set up an inquiry office for prisoners of war, which would register information regarding internments and transfers, releases on parole, exchanges, escapes, admissions into hospital, deaths, as well as other information [...]'. At some point during the conflict lists containing such information were exchanged between the warring nations through IPWA. IPWA could also be used as a tracing service for finding prisoners of war. This was not an exclusive IPWA business; relief societies in neutral countries provided such services as well and were sometimes seen by the Red Cross as competitors. (Lith Van 2011: 23, 44-45).

The IPWA Archives, running from 1914-1923, were submitted by ICRC and inscribed to UNESCO's Memory of the World Register in 2007. Important parts of these archives have since been put online by ICRC to commemorate the centenary of the Great War.

The 'Serbian army main file' of these archives includes 8221 index cards of individual Serbian prisoners of war, and 5576 sheets containing lists of camp populations, military hospital populations, transfers and deaths of Serbian prisoners of war and civilian internees in Central Power captivity between 1914 and 1919. The vast 
majority (75 per cent) is formed by German lists, which span the whole conflict, while there are significantly fewer (21 per cent) Austro-Hungarian lists, mainly pertaining to the beginning of the conflict, and almost no (4 per cent) Bulgarian lists, provided in 1917 only. $^{2}$ Nevertheless these archives can help us understand and assess the numbers of Serbian prisoners of war in Central Power captivity.

After the war the National Assembly of the Weimar Republic installed a Committee of Inquiry on the Responsibility for the World War. Its third subcommittee dealt with 'humanitarian law during the World War'. Hence the figures it published in 1925 on captivity of officers and rank-and-file during the war reflect the official position of the German parliament. Beyond any doubt it used the information collected by the German Inquiry Office, the Zentral-Nachweise-Büro, of the Ministry of War.

The arguably most reliable Austro-Hungarian figures are the ones used in the 1931 compilation 'In Feindeshand' (In the Hands of the Enemy) collected by Dr. Leopold Kern. Following the breakup of the Austro-Hungarian Empire, it is unlikely that the information collected by the Austrian-Hungarian Gemeinsames Zentralnachweisebureau (Joint Inquiry Office) was either complete, or available for study.

The figures can be found in Table 1 below, from which it becomes apparent that Italian, Montenegrin, Romanian and Serbian prisoners of war had higher-thanaverage mortality rates both in Austrian-Hungarian and in German captivity. (Fischer 1927: 19 and Weiland 1931: II (annex)). ${ }^{3}$

2 For the index cards see ACICR C G1 E 13-01 through ACICR C G1 E 13-15, for the lists see ACICR C G1 E 06-01.01 through ACICR C G1 E 06-01.20 [fiches PS1-PS5576]. The index cards cover a very small proportion of the lists, which are largely not indexed nor properly described. The statistics are therefore compiled by the author. The non-indexed lists can be accessed by visiting the ICRC Archives website on https://grandeguerre.icrc.org/en/File/Details/5593771/12/2/ (visited 8 January 2018) and keying in the PS number (between 1 and 5576).

3 In all tables 'British' means 'British and Commonwealth'. 


\begin{tabular}{|c|c|c|c|c|c|c|c|c|c|}
\hline & \multicolumn{3}{|c|}{ Austria-Hungary } & \multicolumn{3}{|l|}{ Germany } & \multicolumn{3}{|c|}{ Austria-Hungary and Germany } \\
\hline nationality & captured & died & $\begin{array}{l}\text { mortality } \\
\% \text { o }\end{array}$ & captured & died & $\begin{array}{l}\text { mortality } \\
\%\end{array}$ & captured & died & $\begin{array}{l}\text { mortality } \\
\% \circ\end{array}$ \\
\hline Albanian & 1416 & 80 & 56 & & & & 1416 & 80 & 56 \\
\hline American & & & & 2457 & 59 & 24 & 2457 & 59 & 24 \\
\hline Belgian & & & & 46,019 & 1004 & 22 & 46,019 & 1004 & 22 \\
\hline British & 158 & & & 185,329 & 5547 & 30 & 185,487 & 5547 & 30 \\
\hline French & 652 & & & 535,411 & 17,308 & 32 & 536,063 & 17,308 & 32 \\
\hline Italian & 369,558 & 26,000 & 70 & 133,287 & 7746 & 58 & 502,845 & 33,746 & 67 \\
\hline Japanese & & & & 107 & 0 & 0 & 107 & 0 & 0 \\
\hline Montenegrin & 12,947 & 970 & 75 & 5 & 0 & 0 & 12,952 & 970 & 75 \\
\hline Portuguese & & & & 7107 & 164 & 23 & 7107 & 164 & 23 \\
\hline Romanian & 52,789 & 4200 & 80 & 147,986 & 25,647 & 173 & 200,775 & 29,847 & 149 \\
\hline Russian & $1,268,977$ & 63,000 & 50 & $1,434,529$ & 75,989 & 53 & $2,703,506$ & 138,989 & 51 \\
\hline Serbian & 154,631 & 15,000 & 97 & 28,746 & 1874 & 65 & 183,377 & 16,874 & 92 \\
\hline TOTAL & $1,861,128$ & 109250 & 59 & $2,520,983$ & 135,338 & 54 & $4,382,111$ & 244,588 & 56 \\
\hline
\end{tabular}

Table 1: Casualties in Austro-Hungarian and German captivity. 
After the armistice was concluded the Serbians, together with their French allies who were 'on the left bank of the Rhine [sic!] (Cahen-Salvador 1929: 275)', were concentrated in German camps and then repatriated - partially by barges via the Rhine towards the Netherlands, from which they were shipped to France by sea - before they continued their journey home. ${ }^{4}$ Others, including British, Italians and Belgians, entered the Netherlands almost exclusively by train. Roughly $10 \%$ of all prisoners of war remaining in Germany were repatriated via the Netherlands.

In 1924 the Dutch Inquiry Office or Informatiebureau published the mortality statistics of almost a quarter of a million Entente soldiers who were repatriated from Germany via the Netherlands between November 1918 and spring 1919. They could not be verified because the office's Great War archives were destroyed in World War II during the accidental bombing of the Bezuidenhout area of The Hague by the RAF. Instead verification was done using the registries of death registers of the municipalities involved. That verification brought to light that while some soldiers included in the figures had already died before repatriation started, others had not been included at all. (Stienen 2016: 349, and Vendrig et al. 2016: 34). ${ }^{5}$

\begin{tabular}{|l|r|r|r|}
\hline nationality & repatriated & died & \multicolumn{2}{|l|}{$\begin{array}{l}\text { mortality } \\
\text { Belgian }\end{array}$} & 17,755 & 4 & 0 \\
\hline British & 54,603 & 31 & 1 \\
\hline French & 119,019 & 61 & 1 \\
\hline Italian & 15,980 & 30 & 2 \\
\hline Portuguese & 4308 & 3 & 1 \\
\hline Russian & 6021 & 5 & 1 \\
\hline Serbian & 4316 & 86 & 20 \\
\hline TOTAL & 222,002 & 220 & 1 \\
\hline
\end{tabular}

Table 2: Mortality among servicemen repatriated via the Netherlands.

4 Cahen-Salvador continues by exclusively mentioning camps on the right bank of the Rhine: six between Rastatt and Frankfurt, one in Wahn (Cologne) and one in Friedrichsfeld (Wesel) (compare Boucabeille 1919: 6, 'Chronique' 1919: 40, and Vendrig et al. 2016: 22-23).

5 Leclercq mentions 92 Serbians, 24 Italians, 4 Russians, 3 Portuguese, 28 Britons, 41 French, and 10 Belgians. (Leclercq 1924: 144-145). The numbers of Italians, Britons and French were reported too low, because almost all of the casualties in the auxiliary hospitals set up in Rotterdam by the Red Cross or the legations of the Entente countries, were missing. The Russians reported by the Red Cross include one casualty in Maastricht who died before 1918, while two in Oldebroek were omitted, because they died in May 1919, whereas the Red Cross reported only until March 1919 (yet the two died during repatriation). 
The mortality rates of prisoners of war who died during the post-armistice repatriation follow the pattern we have seen in Austro-Hungarian and German captivity: on average, more Serbian and Italian prisoners of war than other nationalities died. In case of the Serbians this is even true if the numbers are corrected for the influence of the Spanish flu outbreak on board of the Rhine steamer 'Blücher', as a result of which 66 Serbians died. (Vendrig et al. 2016: 25). If these 66 and the total of 1026 on board are subtracted, the mortality of Serbian prisoners of war repatriated via Netherlands is still 6 per mille (over a three-month period).

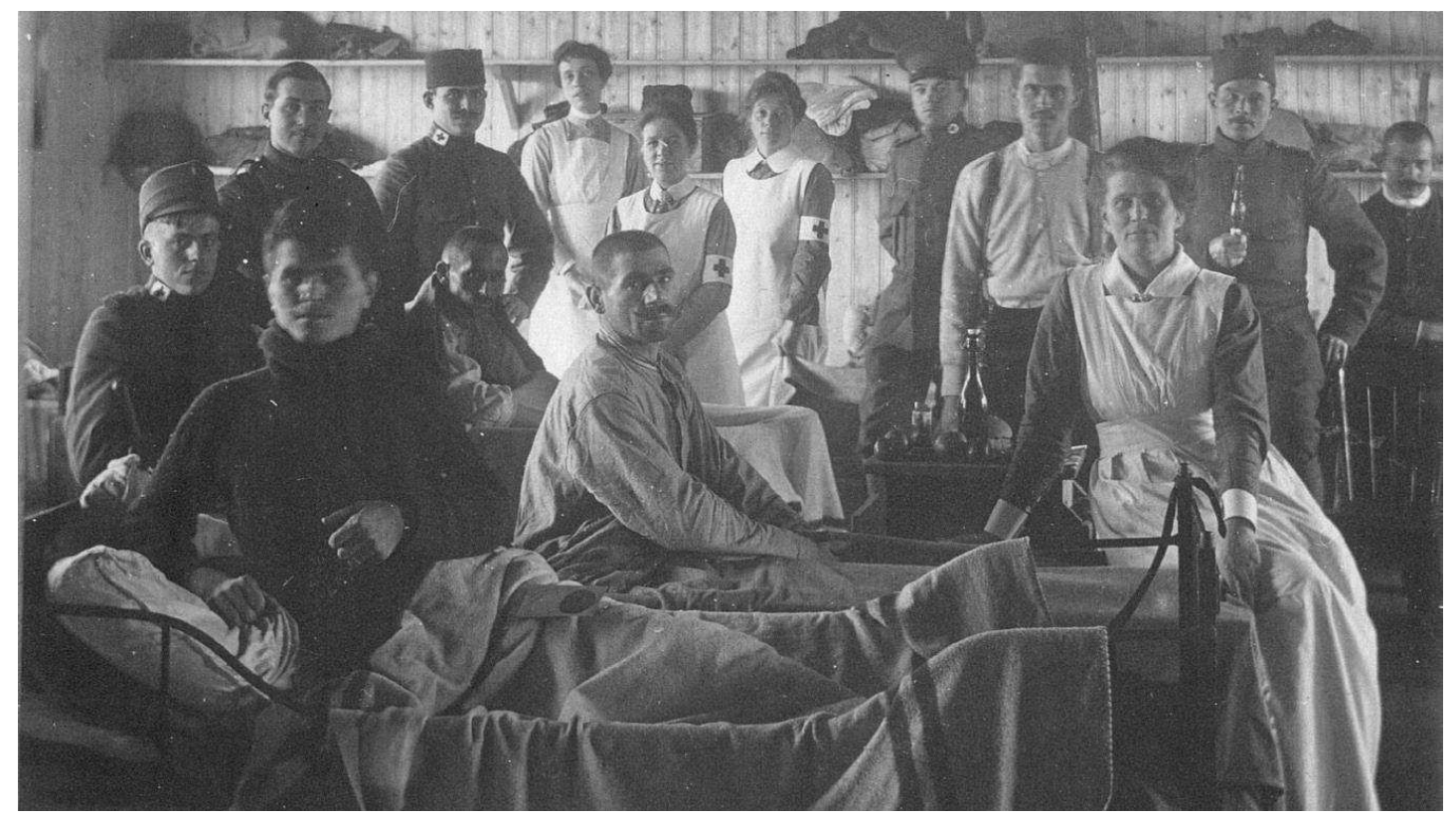

Figure 1: Serbian prisoners of war being treated in army barracks at Nieuw-Milligen, February 1919 (private collection).

\section{Parameters which define First World War captivity}

Jones identifies several key structural parameters which defined First World War captivity: pre-war international law, class (rank and file soldiers vs. officers), the need for additional wartime workers, inspection systems, and differentiation on the basis of a prisoner's origin - usually politically rather than racially motivated. (Jones 2009: 26-40).

In the book he wrote within a year of the us joining the war, Daniel J. McCarthy systematically assesses his observations in Pow and internment camps and their sub-camps vis-à-vis international humanitarian law, the legal corpus comprised of the Geneva Conventions and the Hague Conventions. McCarthy had served in the American Hospital in Neuilly, France in 1916, and then travelled to Germany to investigate the conditions of allied prisoners on behalf of the us in the capacity of protecting power of Great Britain and Serbia. 
Especially articles 6 and 7 of the Regulations annexed to the Convention are meaningful in this respect, to the extent that they can explain differences between the circumstances and treatment of the prisoners:

Art. 6. The State may utilize the labour of prisoners of war according to their rank and aptitude, officers excepted. The tasks shall not be excessive and shall have no connection with the operations of the war. Prisoners may be authorized to work for the public service, for private persons, or on their own account. [...]

Art. 7. The Government into whose hands prisoners of war have fallen is charged with their maintenance. In the absence of a special agreement between the belligerents, prisoners of war shall be treated as regards board, lodging, and clothing on the same footing as the troops of the Government who captured them.

The way article 6 was implemented in the camps and sub-camps of Austria-Hungary and Germany meant that the 'class' and 'need for workers' parameters identified by Jones can be operationalized in at least four ways: while officers were exempt from work, rank and file were employed either for public service or for private persons, or behind the front - which had a connection with the operations of the war and hence was in clear violation of this article.

The maintenance of prisoners can be divided into general living conditions, which were an issue at the beginning of the war, and the food situation, which gradually deteriorated in the course of the war, until it reached unsustainable levels by 1917.

In case of the Serbian prisoners of war, the 'differentiation' parameter has not been observed very often in the sense meant by Jones (reprisals). All other aspects will be analysed in the remainder of this article.

\section{Maintenance and utilization of labour}

The Austro-Hungarian authorities were largely unprepared to house and feed the tens of thousands of enemy servicemen who fell into their hands from the summer of 1914 onwards. Simultaneously, suspect and non-suspect Serbians were interned in internment camps inside the country. The authorities built large camps, but had little experience in how to manage them. The typhus epidemic that raged through various Austro-Hungarian camps in the winter of 1914-1915 is exemplary for this. Typhus broke out in October 1914 in the camp of Nagymegyer, leading to the death of more than 5000 Serbians. At the beginning of December two groups of 1200 prisoners each were moved from Nagymegyer to Mauthausen, where another 7000 Serbian prisoners of war died during that epidemic. ${ }^{6}$

6 Zatková studied Nagymegyer (now Velký Meder). (Zatková 2013: 49), while a 2009 press release mentions 5153 graves in Vel'ký Meder (www1 2009). For Mauthausen the contemporary Laffan mentions 8000 (Laffan 1918: 255-256), while according to the burial records approximately 7,000 Serbians were buried there. (www2 2015). 
Following the 1915 harvest and initial soil preparation Germany had transferred prisoners of war from agricultural projects to mines and industry. The 'increasing need' for workers led to a transfer of all able-bodied prisoners of war from the base camps to be employed. (Fischer et al. 1927: 331). Colonel Friedrich at the War Ministry in Berlin described these circumstances to an official delegation of the International Committee of the Red Cross as 'Not kennt kein Gebot'.'Necessity has no law. (Hinz 2005: 266).' Employing prisoners of war served a dual purpose: it would free the German ablebodied men to go to the front, while the labour provided by the prisoners of war would keep the German war economy going. (Rawe 2005: 78).

Austria-Hungary had had a poor harvest in 1915 and by January 1916 their reserves were depleted. István Tisza, the Prime Minister of the Kingdom of Hungary, continued to sell Hungarian surplus grains to primarily the Armeeoberkommando (the Army's High Command) and thus denied cereal crops to the starving Austrian civilian populace. Many areas received food on an ad hoc basis and even that was only possible because Germany sent considerable economic aid. (Herwig 2014: 275, Dowling, 2005: 260, and www3).

A few months before, in October-December 1915, when Serbia fell to a combined German, Austrian and Bulgarian invasion, 124,000 Serbians became prisoners of war in the hands of the German and Austro-Hungarian armies. They arrived in Austrian and Hungarian camps at the end of 1915. (Herwig 2014: 160, and Denda 2015: 21-22).

On 19 and 20 January of the next year, 3175 Serbians were transferred from Braunau in Bohemia (Austria) to Königsbrück in the Kingdom of Saxony (Germany), followed on 23 January by 1200 from Braunau to Soltau in the Prussian Province of Hanover (Germany). Around the same time there was a transport of 971 Serbians from Braunau to the camp near Celle (Hanover) and another 700 from Heinrichsgrün in Bohemia (Austria) to Soltau. Also 2977 Serbians arrived in Stargard in Pomerania (Germany). On 21 and 22 May 1916, another group of 2800 Serbians was transferred from Aschach (Austria) to the Lechfeld area in Bavaria. ${ }^{7}$

The French athlete and rugby player, Géo André, who competed in the 1908 and 1912 Olympic Games, saw the arrival of the Serbians in Soltau from Austria. He describes it as follows:

During my stay at Soltau, I witnessed one of the saddest sights I have ever seen: the arrival of the Serbians. I will never forget that gruesome parade. Emaciated, tottering, haggard, they lingered. The few kilometres' walk from the station used up their last strength; all they wanted was to get a suitable place and drop down.

7 For Braunau i. B. (now Broumov) to Soltau see ACICR C G1 E 06-01.6: PS1634-PS1676 and ACICR C G1 E 06-01.8: PS2032-PS2069, for Stargard see ACICR C G1 E 06-01.7: PS1700-PS1816, for Braunau to Königsbrück see ACICR C G1 E 06-01.8: PS2094-PS2250 and ACICR C G1 E 06-01.9: PS2251-PS2411, for Heinrichsgrün (now Jindřichovice) to Soltau see ACICR C G1 E 06-01.9: PS2417-PS2436, and for Aschach a/d Donau to Lechfeld see ACICR C G1 E 06-01.10 PS2666-PS2709. 
He continues:

Moved by the desperate look in their eyes, we gave them some bread, any kind of food. The sentries rushed over to them to prevent them from accepting, and threatened them with bayonets. But the Serbians, less passive than the Russians, stood up, with sparkling eyes, and their pride rebuffed their jailers (André 1918: 120-121).

Officers are conspicuously missing among the Serbian prisoners transferred to Germany: the only four (!) arrived between the summer of 1917 and the spring of 1918. As officers were not allowed to work, this may be an indication of a 'wheat for labour' scheme between Austria and Germany. The subcommittee report actually confirms the transfer of the Serbians 'from Austro-Hungarian prison camps'. (Fischer et al. 1927: 333). Transfer of prisoners of war between detaining powers was not uncommon, neither between the states of the Entente, nor between the Central Powers. However, this was not regulated by international humanitarian law at the time. (Gross 2006: 206).

In the case of the Serbian prisoners of war it seems that such a deal was beneficial for all sides: the Austrians would have fewer mouths to feed and could prevent their own population from starvation, the Germans could offer wheat and were looking for workers to fill the places that had become vacant in agriculture, while the Serbians - who were of course no party in the deal - saw their general conditions and chances of survival improve.

Similarly, two years later after the Italians had lost the Battle of Caporetto, the Austro-Hungarians and Germans split the human loot into halves - only this time Germany did take almost 4,500 officers as well. (Hoffman 1920: 73, Procacci 2006: 198, and Nachtigal 2008: 356).

While also tens of thousands of Serbian prisoners of war were held captive in Hungarian camps, such as Nagymegyer, Boldogasszony and Sopronnyék ${ }^{8}$, no traces of similar mass transports from the Hungarian part of the empire were found in the archives of IPWA.

In August 1916 the Germans employed their 1.6 million prisoners of war (including 12,000 enemy civilians) in Germany and the occupied areas as follows (Fischer et al. 1927: 333):

8 Boldogasszony (now Frauenkirchen), and Sopronnyék (now Neckenmarkt) are in Burgenland, that became Austrian in 1921. 


\begin{tabular}{|l|r|r|}
\hline kind of employment & \multicolumn{1}{l|}{ number } & \multicolumn{1}{l|}{ fraction } \\
\hline home front Arbeitskommandos & & \\
\hline - agriculture & 735,000 & $45.2 \%$ \\
\hline - industry & 331,000 & $20.4 \%$ \\
\hline - public utility & 39,000 & $2.4 \%$ \\
\hline rear area & 253,000 & $15.6 \%$ \\
\hline other & 267,000 & $16.4 \%$ \\
\hline TOTAL & $1,625,000$ & \\
\hline
\end{tabular}

Table 3: Employment of prisoners of war in Germany.

Little is known about the forced labour that the soldiers who died in Netherlands during repatriation had had to endure in Central Power captivity. NCO Đorđe Vukosavljević from Kragujevac, who was transferred from Braunau to Cellelager early 1916, and then from Cellelager to Soltau, wrote to his wife how he nearly turned blind due to working in the potash salt mines in the Aller-Leine Valley. (Vendrig et al. 2016: 17-20). ${ }^{9}$ He died on 22 January 1919 in Nieuw-Milligen.

The Serbian soldiers who were repatriated via the Netherlands after the armistice were not the first Serbians who reached that country as a result of the conflict. In the summer of 1918, the journalist and writer Henri Habert had already interviewed 37 Serbian prisoners of war who had escaped from camps in Germany, and had reached the Netherlands.

29 of these men described their labour conditions in German captivity. A majority of 21 mention agriculture in various forms, one of whom, Borisav Nastasović, operational medical orderly in the $8^{\text {th }}$ Infantry Regiment, also describes how he was unloading coal in the port of Emden, before being sent to the Krupp family estate in Klausheide. Only Milovan Stefanović describes having been employed at a factory 'supporting the war effort', while Aleksandar Mitić from Veliko Gradište describes how he worked in the coal mine 'Grube Adolf' in Herzogenrath-Merkstein, just $3 \mathrm{~km}$ from the Dutch border, in a group of 50 Serbians. (Habert 1918: 15, 16, 33).

In 1925 the subcommittee of the German Parliament concluded that the Serbians in Germany, who had primarily been employed in agriculture, but also to a lesser degree 'in mining etc.', had proven themselves to be a 'good and willing labour force (Fischer et al. 1927: 334).'

Similar to Habert's booklet, a more well-known work was compiled in Saloniki by Archibald Reiss, who interviewed Serbian prisoners of war who had escaped from Austria via Switzerland. Both works were published in 1919 and served the purpose of accusing the Central Powers of not respecting the Hague Conventions. Reiss made a case of several soldiers who were sent to work behind the front near Bozen (now Bolzano), Meran (now Merano), and Sulden (now Sulda), all in South

9 Otte describes the injuries inflicted by the salt mining of Soltau's PoWs. (Otte 2016: 188). 
Tirol. ${ }^{10}$ In their claims at the Paris Peace Conference the Kingdom of Serbs, Croats and Slovenes mentioned that ' 30,000 Serbian prisoners were sent to the Italian front to perform works behind the front, [of which] only 5,000 returned'. Such claims could not be substantiated. ${ }^{11}$ Similarly no proof has been found of any large-scale employment of Serbian pows behind the front by the German army. It should of course be noted that both surveys are geographically biased: Reiss interviewed mostly Serbians who arrived in the Müstair valley in Switzerland, which was close to the front, while Habert mainly interviewed Serbians who escaped to the Netherlands from the predominantly agricultural area of Emsland.

Escape to neutral countries, as described by Habert and Reiss, is regulated by article 13 of the Hague Convention number V:

Art. 13. A neutral Power which receives escaped prisoners of war shall leave them at liberty. If it allows them to remain in its territory it may assign them a place of residence.

The same rule applies to prisoners of war brought by troops taking refuge in the territory of a neutral Power.

Significant numbers of prisoners of war who escaped from German captivity can be found among Russians (69 per mille), Serbians (22 per mille), Belgians (12 per mille), and French (9 per mille). These are accumulated figures for the whole duration of the war. (Doegen 1921: 28-29). ${ }^{12}$ Again these numbers mainly include rank and file soldiers. The numbers seem to be higher among men from nations (Russians, Serbians) the Germans had primarily employed in agriculture. Another group that stands out are the countries relatively close to Germany, who could more easily reach their armies via Netherlands or Switzerland. Article 13 implied that escaped prisoners of war, who were left at liberty by the neutral state could travel back to join their army units. Belgians and French, for example, had a geographical advantage in this respect.

637 Serbians escaped from German captivity between 1916 and 1918. The German Empire shared land borders with three neutral countries: Switzerland, Denmark and the Netherlands. The number of Serbs who escaped to Netherlands is unknown. The numbers of escapees were not registered, as they were to be left at liberty, which the Dutch took rather literally. Contemporary newspapers mention at least 165 escaped Serbian prisoners between 1916 and 1918, of which 22 in the provinces of Groningen and Drenthe in 1918, while Habert interviewed 37 in the summer of that year in the province of Overijssel. Therefore, it is a fair assumption that at least 200 Serbians reached the Netherlands. Five of these died, less than 25 per mille. The first died on the border during his escape, two more died of disease

10 See the testimonies of Božidar Mladenović, Krsta Simić, Velizar Bradilović, Isajlo Milosavljević, Aleksandar Jovanović and Miloje Živanović (Reiss 1919: 7, 10-12, 14-16, 9).

11 Rapport sur les dommages de guerre (1919: 20), compare the 346 war graves in post-war Italy (Stefanović 1926: 130).

12 Note the exceptionally high number of escaped Russians, which requires further research, but may be a result of the conclusion of the peace between the Central Powers and the Soviet Union on 3 March 1918. 
(kidney failure, tuberculosis), one of carbon monoxide poisoning and the fifth of an unknown cause, while he was probably working in a glass factory. (Stienen 2016: 337, and Vendrig et al. 2016: 15-17)..$^{13}$

It is unclear if any successful attempts were made by Serbian soldiers to reach Denmark, and for Switzerland no statistics on escape and mortality were found.

The increase in successful attempts to escape is an indicator that the longer the war lasted, the more the prisoners of war felt that their situation became unbearable, especially regarding food and labour. This increase was in spite of the measures the Germans took to prevent escape, which was neither in the interest of the German war effort, nor the German war economy. (Rawe 2005: 134).

Indeed, the situation of prisoners of war in Austria-Hungary and Germany should be seen in the context of the shortfall in supplies from 1916 onwards, and the inability or unwillingness of some governments to complement the food rations the Central Powers were able to provide.

According to a note sent by the Italian High Command's Information Section $\mathrm{R}$ to the Prime Minister and several other cabinet members:

While the Italians were treated miserably in Habsburg captivity, the worst treatment was reserved for the Serbs. The Italian high command received reports that the Serbs received no food parcels, and those who did not work and were often ill were kept like animals in cages. The only nutrition they had were the remnants of inedible bread, carrots, and uncooked turnips which the Austrians threw through the bars (Kramer 2008: 67).

Interesting enough, at the same time

[the reasons for] the death of one sixth of the Italian prisoners of war were similar to those that led to the death of numerous Russians, Serbians, and Romanians: while it was, however, impossible for the governments of the latter three countries to supply provisions to the prisoners of war of their own armies, the Italian state was simply not prepared to do so (Procacci 2006: 198).

While British, French and Belgian prisoners of war managed to add 950 to 1200 kilocalories to their daily menu from the parcels they received, the Russians for example could add only 200 kilocalories - if any at all. (Rawe 2005: 106, and Speed 1990: 74-75).

13 The possibility hypothesized by Ristic that the Dutch 'colleagues of Van Tienhoven' would need to assist Serbian warriors 'on Dutch soil' became reality in Rotterdam where the Serbian soldiers who fell ill there in 1918 and 1919 were treated by dr. Van Dijk, who had led a Dutch medical mission for the Serbian Red Cross in Monastir from December 1916 to April 1917. (Ristić 2016:15, and Stienen, 2016: 346). 


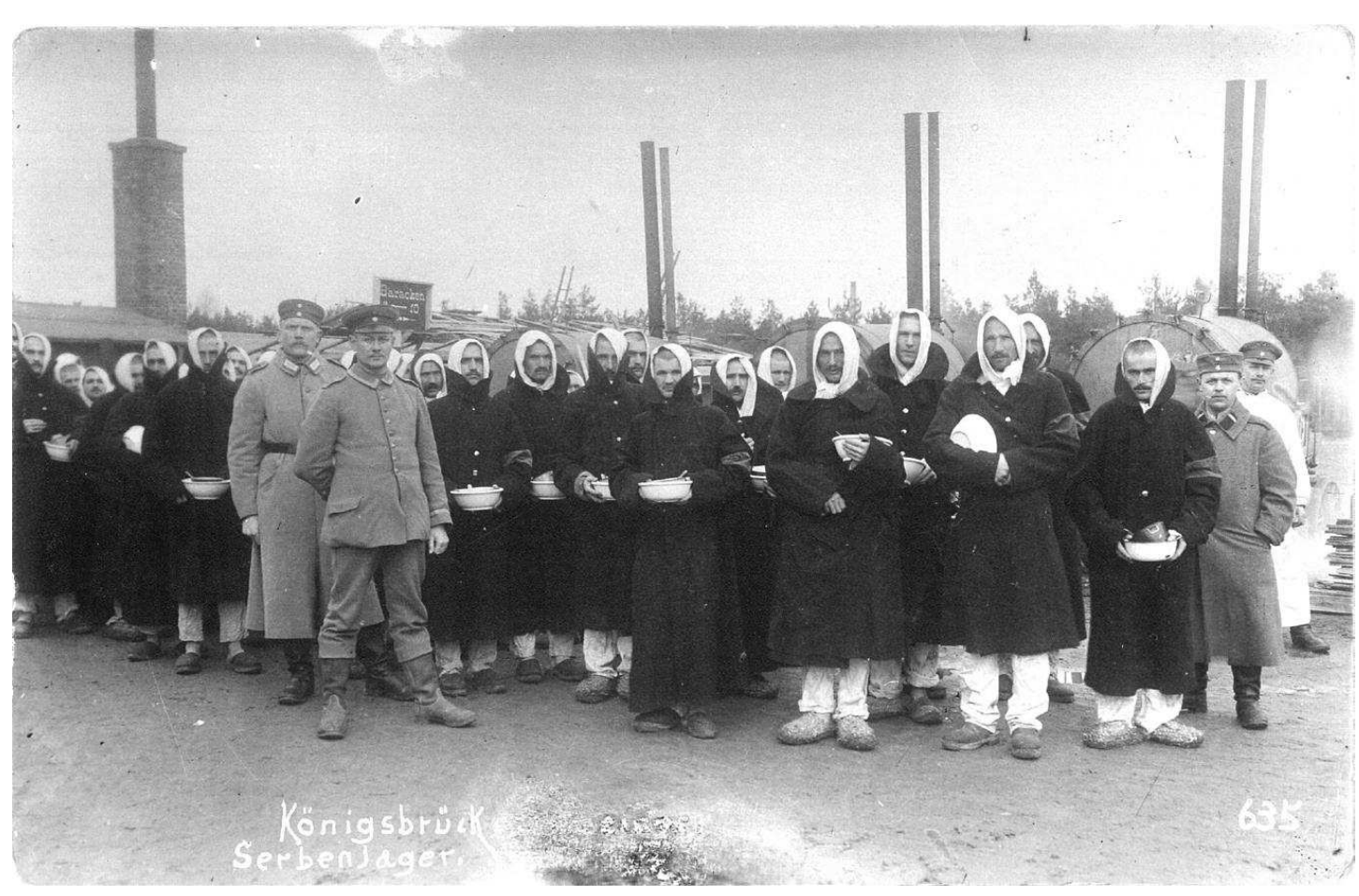

Figure 2: Serbian prisoners of war at Königsbrück before the distribution of rations (private collection).

Only few statistics regarding the number of parcels received by prisoners of war remain. Those for Königsbrück are interesting because it was one of the largest camps for Serbians in Germany. On 27 October 1914 the camp already had more than 14,500 prisoners of war. They arrived in batches. When ICRC visited the camp on 13 January 1915, there were 5924 French and 8676 Russians. A second visit, two months later, found 5405 French and 8591 Russians there. As we saw 3175 Serbians arrived by 20 January 1916. After the Italian Second Army collapsed at Caporetto, more than 2000 Italians joined the others. Towards the end of the war the numbers were 4029 French, 2225 Italians, 2746 Serbians, and 6078 Russians.

The following extrapolated numbers of average number of prisoners per nationality, and the estimated duration of their stay, can be used to calculate the number of parcels per man, per month. ${ }^{14}$

\begin{tabular}{|l|r|r|r|r|}
\hline nationality & men & months & parcels & parcels /man /month \\
\hline French & 5100 & 44.1 & 975,343 & 4.34 \\
\hline Italian & 2200 & 6.0 & 21,202 & 1.61 \\
\hline Serbian & 2900 & 29.3 & 10,227 & 0.12 \\
\hline Russian & 7600 & 44.1 & 128,637 & 0.39 \\
\hline TOTAL & & & $1,135,409$ & 1.74 \\
\hline
\end{tabular}

Table 4: Parcels distributed in Königsbrück until 1 July 1918.

14 Numbers were reported for January 1915 (Comité International du Croix Rouge 1915a: 76), March 1915 (Comité International du Croix Rouge, May 1915b: 53), and October 1918 (Doegen 1921: 18-19), see note 7 for the arrival of the Serbs, the number of parcels was found in Doegen (1921: 85). The French and Russians are assumed to have arrived in October 1914, the Serbians on 20 January 1916, the Italians in January 1918. The camp's strength is assumed to fluctuate between 14,500 and 15,000 , the ratio of Russians to French 3:2. 
Whereas the French received exactly one parcel per week on average, the Serbians only received one parcel per eight months, during their almost two and half years in the camp.

Conrad Hoffman jr., who was Senior Secretary of YMCA's War Prisoners' Aid in Germany, and who visited pow camps, describes the situation in the camps at the end of 1917 as follows:

The increasing shortage of food and clothing in Germany had dire consequences for the prisoners of war who were dependent upon the Germans for their food. The Russians, Serbians, and Roumanians suffered most, and increasing difficulties for our work resulted (Hoffman 1920: 116-117).

\section{Relief societies: charitable effort and inspection}

The Serbian humanitarian effort during World War I, to complement via neutral countries the insufficient food rations the Germans and Austro-Hungarians were able to provide, cannot be seen separately from the role played by the descendants of Jevrem Grujić (1827-1895). He was a senior statesman and diplomat for the Kingdom of Serbia in the second half of the nineteenth century. His only son, dr. Slavko Grujić (1871-1937), became a statesman and diplomat as well. On 23 July 1914, as Secretary General of the Serbian Ministry of Foreign Affairs, he assisted at the presentation of the ultimatum by Baron Giesl von Gieslingen, which was to lead to the AustroHungarian declaration of war on 28 July. In November 1916, he was appointed Envoy of the Kingdom of Serbia to the Swiss Confederation. He had met his American wife Mabel, née Dunlop (1872-1956), in Athens after she went to study there in 1901. Slavko had two sisters: Mirka (1869-1940) and Stana (1860-1942). Both were members of the Belgrade Women's Society. Later Mirka continued to work within the Serbian Nurses' Circle, where she worked as a volunteer nurse during the First Balkan War. Of the three siblings only Stana, who married Stevan Curčić (1850-1932), a journalist and senior civil servant, had offspring. Her daughter Jelena Ćurčić (1883-1966) married the diplomat Milan Milojević (1874-1969). Milojević received his doctorate degree at the Sorbonne in 1905, and then quickly rose through the ranks of the diplomatic service, where he worked in Sofia and Priština. Early 1917 he was appointed Chargé d'Affaires to the Kingdom of the Netherlands in The Hague, which until then the Envoy in London had dealt with. ${ }^{15}$

The Oeuvre internationale pour blessés et prisonniers de guerre ('International charity for the wounded and prisoners of war') was founded in Maastricht, the Netherlands, in 1915 and recognized by the Dutch state on 15 August 1916. The Oeuvre was by far the largest in its kind in the Netherlands, being responsible for more than 90 per cent

15 Unless specified otherwise most details on the extended Grujić family were taken from Milanović (2015). 
of all parcels sent from the Netherlands during the war. ${ }^{16}$

While Maastricht was the administrative and logistic centre, many local committees and sub-sections per nationality sprang up throughout the country. A French section, for example, was established in The Hague at the beginning of 1916. It allowed the general public to adopt deprived prisoners of war in Central Power captivity, for which the committee would accept donations in money or in kind. The adoption meant that the committee could send two parcels per month, for fixed amounts of 1.5 to 5 guilders. Depending on the amount such parcels would contain only food, or food and clothes. ${ }^{17}$

In July 1916, the Oeuvre published a letter it had received from two Serbian civilian internees held at Gyöngyös, in which they ask the committee for support. ${ }^{18}$ Two months later three prisoners of war sent a letter of gratitude after the committee had sent 100 parcels paid from the funds they had raised:

During the nine months we have spent here as prisoners of war, we have not yet experienced any sign of compassion from anyone. We received the first charity from your committee. All other prisoners, Russians, French, British, receive food, but no one thinks of us Serbians. If possible and if our request doesn't appear to be too immodest, we pray for you to remember us in the future. There are 860 Serbians in this camp, among which some 40 ill, but apart from that there are many elderly and weak among us. ${ }^{19}$

The Serbian section of the Bureau de secours aux Prisonniers de guerre ('Bureau of Relief to Prisoners of War') in Berne was set up in May 1916 on the initiative and at the request of the Serbian Relief Fund in London for the purpose of sending food and clothing to Serbian prisoners, both military and civilian, interned in Germany and Austria-Hungary. After the arrival of Slavko Grujić at the end of the year, his support and political weight, combined with the benevolence of the Swiss people, made the section the de facto coordination point of all Swiss aid for the benefit of Serbians held by the Central Powers. (Bondallaz 2013: 421).

Milan Milojević, married to Slavko Grujić niece, presented his letter of credence to Queen Wilhelmina of the Netherlands on 17 February $1917 .{ }^{20}$ One month later a Serbian sub-section of the Oeuvre was founded in The Hague, at the same address as the French sub-section. The Serbian diplomat's wife Jelena and her aunt Mirka were

16 According to Leclercq the Oeuvre was responsible for 2,536,265 parcels out of the grand total of 2,749,343. (Leclercq 1924: 121). Not much, if we realize that a single camp like Königsbrück received more than one million parcels.

17 Office d'information (1916: 368-369).

18 'Internationaal liefdewerk voor gewonden en krijsgevangenen', Nieuwe Rotterdamsche Courant, 6 July 1916, p. 8.

19 'Voor de Servische krijgsgevangenen', Nieuwe Rotterdamsche Courant, 31 August 1916, p. 1.

20 'Hofberichten', Provinciale Geldersche en Nijmeegsche courant, 18 February 1917, p. 2. 
among the founding members. ${ }^{21}$ Jelena’s sister Mica Curčić was also involved. Among the four escaped prisoners who helped them were a certain Stefanović, a banker from Novi Sad, and Aleksandar Mitić, one of the soldiers interviewed by Habert after his escape. Besides donations from private initiative the embassy received a significant sum from the 'royal government', which it spent on sending parcels to Austro-Hungarian and German camps. (Milojević 1994: 169). ${ }^{22}$

\section{Potvrda posiljke br}

\section{KRIEGSGEFANGENEN-KARTE}

Ratni zarobljenik koji ovu ne povrati ne dobije u buduce drugih posiljka.

BILJEZKE
INTERNATIONALES LIEBESWERK

$$
\text { FÜR KRIEGSGEFANGENE }
$$

(Serbische Abteilung)

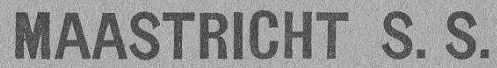

(HOLLAND).

Figure 3: Pre-addressed acknowledgment of receipt for food parcels issued by the Oeuvre for use by Serbian prisoners of war (private collection of Hans van Lith).

From the Netherlands there were individual and collective shipments of parcels to camps in Germany and Austria-Hungary. Compared to for example the Belgians, the Serbians received much more collective than individual shipments. In the case of Belgian, British and French soldiers in German captivity, their respective governments supplemented the rations with food deliveries - particularly bread. Relief societies supported individual soldiers in need. In the case of Serbia, where the government was less in a position to supplement the food rations, relief societies in neutral countries concentrated more on supplementing food rations and less on having individual Serbian servicemen adopted. Indeed, the needs of the Serbians in 1916 were different from those of the Belgians, French and British in 1915.

If we compare the shipments in 1918 to Belgians and Serbians by the Oeuvre, the Belgians received 183,717 individual parcels on a total of 200,903 (91.4 per cent),

21 'Steun aan Servische krijgsgevangenen', Nieuwe Rotterdamsche Courant, 17 March 1917, p. 1.

22 Unlike Milanović (2015), who interprets 'royal government' as that of the Netherlands, it seems that Milojević meant the royal Serbian government; given the neutrality policy of the Netherlands it could not financially support a belligerent state. 
whereas the Serbians received 373 individual parcels on a total of 14,395 (2.6 per cent). ${ }^{23}$ It was probably more effective to have the Serbian help committees in the camps distribute the food than to send individual parcels.

Slavko's wife Mabel Grujić went to her native America in November 1917. As the director of the Serbian Aid Fund in New York, she managed to engage both the American public and Americans of Serbian origin. While her organization, founded as the Serbian Hospitals Fund, first focused on helping Serbian hospitals in Greece, the range of activities gradually broadened to include the care for Serbian officers' and functionaries' families abroad, students in exile, and Serbian boy prisoners held as civilian internees. ${ }^{24}$

The Serbian Sections in The Hague and Berne coordinated their actions. In a letter dated 10 January 1918 the president of the Serbian Section in Berne, Aymon de Blonay, informs Mirka Grujić of his intention to keep sending bread and biscuits to Germany and, in view of the parcels sent by the Serbian section in The Hague, he offers to add 'a can of corned beef for each man' (Radovanović 2017: 61). The Section in Berne had secured the delivery of flour by boat from the British and American Red Cross Societies, which was turned into bread and biscuits in Switzerland, and shipped to the camps in sealed boxcars. (Bondallaz 2013: 421, Topalović 1918: 13, and CahenSalvador 1929: 193-194).

There was an overlap in camps that received aid from Berne and those that received aid from The Hague via Maastricht. The initial list of camps of the Oeuvre consisted of Csánig, Drosendorf, Kautzen, Gyöngyös, Kleinmünchen, Raabs, Schwechat, Katzenau and Parchim, of which only Gyöngyös, Kleinmünchen, and Schwechat were not on the list of Berne. Similarly, ten of the fourteen camps mentioned by Radovanović, including Königsbrück, were served from Switzerland as well. Furthermore, half of these fourteen were camps that had civilian internees besides prisoners of war. ${ }^{25}$ Also the few files of the Serbian Section kept in the State Archives of Belgium indicate that a share of the help from the Netherlands to Serbians in Austro-Hungarian camps was reserved for civilian internees.

After the war both committees published a financial report. Between the summer of 1916 and the armistice the Oeuvre in Netherlands sent 47,069 parcels worth 218,704.83 guilders to Serbians, whereas their colleagues in Switzerland sent shipments worth 4.2 million francs of the money they raised themselves helping up to 68,000 prisoners, and another 8 million francs worth of food and clothes provided by the Serbian Relief Fund and the British and American Red Cross Societies. The most significant donors were the Serbian legation (37.4 per cent), the Serbian Relief Fund (21.6 per cent) and the Serbian Red Cross (20.6 per cent), reaching almost one

23 See Lith van (2011: 122) and 'relevé des colis expedié en 1918 par nationalité' in Algemeen Rijksarchief, toegang BE-A0510 / I 433 WO 1, Internationaal liefdewerk voor gewonden en Krijgsgevangenen te Maastricht, inv.nr. 256.

24 See Serbian Hospitals Fund.

25 See Radovanović (2017: 125), and Serbian Section. 
third of all Serbian prisoners and internees in Germany and Austria-Hungary. The total amount spent by the Swiss-based organization of 12 million francs is roughly 27 times the amount spent by the Oeuvre on Serbian prisoners and civilian internees. And the Bureau de Secours was not even the only organization in Switzerland helping the Serbians. In today's euros the total amount spent on Serbians by the Section in Berne is at least $€ 86.25$ million, whereas the Section in The Hague spent more than $€ 3$ million. ${ }^{26}$

The international humanitarian effort is regulated by Article 15 of the Regulations:

\begin{abstract}
Art. 15. Relief societies for prisoners of war, which are properly constituted in accordance with the laws of their country and with the object of serving as the channel for charitable effort shall receive from the belligerents, for themselves and their duly accredited agents every facility for the efficient performance of their humane task within the bounds imposed by military necessities and administrative regulations. Agents of these societies may be admitted to the places of internment for the purpose of distributing relief, as also to the halting places of repatriated prisoners, if furnished with a personal permit by the military authorities, and on giving an undertaking in writing to comply with all measures of order and police which the latter may issue.
\end{abstract}

While such relief societies almost immediately started acting as the channel for the charitable effort, a few also gradually took their role in the inspection system, using their right to be admitted to the places of internment, similar to delegations from the neutral countries and the International Committee of the Red Cross. Since in practice the admittance to the camps was not allowed for representatives of the belligerents such relief societies were probably intended to operate from neutral countries. (McCarthy 1918: 246).

Initially Serbian interests in Germany were represented by the legation of the United States. When the us entered the war in April 1917 Spain took over as the protecting power. (Berridge 2012: 85-86). Delegates of the us and later Spain visited the German camps on behalf of Serbia and other countries whose interests they represented. As we saw, the International Committee of the Red Cross and for example the YMCA organized similar visits. In Austria the effectiveness of the inspection system decreased when the USA entered the war and their role was only marginally taken over by the Danes, Swedes, and Dutch. (Topalović 1918: 17). The way the us represented the UK's interest shows that the effectiveness of inspection was higher when there was a genuine threat of reprisals on a diplomatic level. Unlike for the British, this was not really the case for the Serbians.

26 Using an exchange rate of 0,489 franc per guilder and the 'Value of the Guilder' tool of the International Institute of Social History (http://www.iisg.nl/hpw/calculate.php visited 8 January 2018). 


\section{Circumstances specific to South-East Europe}

A difference overlooked by many may be that the western armies had vaccinated their soldiers against common infections such as cholera or smallpox, whereas the armies of South-East Europe were less likely to do so. (Overmans 2003: 663). The exact effect of this phenomenon could not be established. Anyway, no effective vaccine against typhus was available during the 1914 and 1915 epidemics.

Romanian rank and file soldiers in Germany had both the highest mortality rates and the highest percentage of casualties caused by disease $(99.2 \%$ of all deaths vs. $0.8 \%$ of earlier wounds, accidents or suicide). They were followed by the Italians (96.2\%), Serbians (95.8\%) and Russians (91.3\%), while others had percentages below the average of $89.2 \%$. (Doegen 1921: 56).

Spoerer analysed pneumonia cases among rank and file soldiers based on the same data. He concluded that mortality was lower the longer a prisoner of war was held captive. This conclusion might have been affected by the effects of the influenza pandemic. An analysis of historical data in Switzerland shows an increase in pulmonary tuberculosis during the Russian and Spanish influenza pandemics. Furthermore, undernourishment is an important risk factor for developing tuberculosis from a latent tuberculosis infection. (Spoerer 2006: 130-131, Zürcher et al. 2016, Rawe 2005: 106, and Cegielski and McMurray 2004).

More than two thirds of the Serbian rank and file soldiers who died in Germany died of some sort of respiratory disease, such as pulmonary tuberculosis or pneumonia - rivalled only by the Portuguese - which may be an indication of Serbian (and Portuguese) soldiers being more susceptible to Spanish flu. Such hypothesis cannot be tested based on the data provided by Doegen, because he didn't record Spanish flu separately, and there are no monthly disease statistics. (Doegen 1921: 56).

At the beginning of the war Serbia had achieved an intermediate level of industrialization'. (Fogelquist 2011: 22). Soldiers from less industrialized societies, such as in South-East Europe, were less fit to be employed in industrial workplaces. (Spoerer 2006: 133). As it is not known in general how the labour was distributed among the Serbians or Romanians, it is difficult to prove to what extent this worked out negatively for the Serbian prisoners of war, especially in Germany.

At the end of 1915 Serbia was 'a region with a weak infrastructure that had already been heavily damaged in previous wars, where the reserves of the economy and the population were already depleted (Kramer 2008: 144).' Indeed many Serbian soldiers had been mobilized two years longer than most other Entente soldiers when the Central Powers took them in captivity. Mobilization in the Balkans started in the autumn of 1912 in the wake of the First Balkan War. One of the Serbians who died in the Netherlands, 40-year-old Dejan Milojević, had participated as a volunteer fighting the Ottomans in Libya during the Italian-Turkish War, after which he had served his motherland in both Balkan Wars and during the Great War. (Vendrig et al. 2016: 2526).

An agreement after the armistice that allowed those who spent the longest time in captivity to be released first, worked against the chances of survival of the 
Serbians: whereas some of them had been mobilized in 1912, half of the other prisoners of war had spent more time in captivity than they did - and would be released earlier. The repatriation statistics available for Germany and the Netherlands confirm that Serbians were repatriated among the last groups and arrived relatively late to the Netherlands. ${ }^{27}$

\section{Conclusions}

The mortality of Italian, Serbian and Romanian prisoners of war was above average in Austria-Hungary, Germany and the Netherlands. Not all factors that may contribute to this higher mortality could be fully assessed and further research is required.

The naval blockade by the Entente had an effect on the ability of Germany and Austria-Hungary to feed the prisoners of war in their custody. When Austrian food stocks were depleted early 1916, shortly after the occupation of Serbia, Germany sent food to relieve the civilian population. In that same year Austria sent almost 30,000 Serbian prisoners of war to Germany, which was eagerly looking for a larger workforce. The Serbian soldiers who escaped to, or were repatriated via, the Netherlands belonged to this group.

The 'Serbian army main file' kept in the IPWA archives at ICRC needs to be examined in more detail. Such research could add to our understanding of the way Germany managed its Serbian forced labour force, and help us to verify sickness and mortality among Serbian prisoners of war in - in particular - German captivity.

Where Germany and Austria-Hungary were unable to feed the prisoners of war in their power, the Entente governments and population would help their fellowcountrymen in captivity in order for them not to starve. Being in exile, the Serbian government relied more than other governments on the work of relief societies and on their allies - particularly the British and Americans - to complement food rations of Serbian prisoners and internees. Unlike their allies, Serbians in captivity would receive collective help, rather than individual parcels. In spite of these efforts Serbians received significantly fewer parcels with food and clothing than soldiers of other nationalities.

The Serbian soldiers, more than any other, were exhausted by 1918, for many had been mobilized for up to six years. Yet they were repatriated among the last groups, mostly early 1919.

More than two thirds of the nearly 2000 Serbians who died in German captivity between 1916 and 1918, died of respiratory diseases, which were related to the Spanish influenza pandemic. Of the 86 Serbians who died in the Netherlands in the first six weeks of 1919, at least 66 can be directly attributed to a single source: Spanish

27 See Hinz (2005: 332) and Speed (1990: 176) on the order of release and Vendrig et al. (2016: 24), and NL-HaNA, BiZa / Armwezen, 1918-1947, 2.04.55, inv.nr. 549 on the number of Serbians repatriated via the Netherlands. Those figures are confirmed by Speed (1990: 219), who used other sources to calculate that by 30 December 1918 only 1257 Serbians from Germany had been repatriated out of 575,024 Entente servicemen repatriated by that date. 
flu. More than $90 \%$ of the casualties among Entente servicemen in Netherlands, whose ages are known, were between 20 and 40 years old.

Undernourished, underclothed, and exhausted after many years of war, captivity, and forced labour, the immune system of the Serbians could not cope with the Spanish flu when it struck.

\section{References}

André, G. 1918. Ma captivité en Allemagne, 1914-1917. Paris.

Berridge, G. 2012. Embassies in Armed Conflict. London.

Bjelajac, M. 2005. 'Stradanje za robljenih srpskih vojnika u Prvom svetskom ratu', in: Genocid u 20. Veku na prostorima jugoslovenskih zemalja, Zbornik radova sa naučnog skupa, Beograd, 22-23. april 2003, ed. by Jovan Mirković. Belgrade, pp. 41-48.

Bondallaz, P. 2013. 'De la charité populaire à la diplomatie humanitaire : l'exemple des secours suisses en faveur de la Serbie', Revue Suisse d'histoire, 63 (3/2013), pp. 405-427.

Boucabeille, P. 1919. 'Le Rapatriement des Prisonniers de Guerre Français à travers la Hollande', Eigen Haard, 45 (1919), pp. 6-7.

Cahen-Salvador, G. 1929. Les Prisonniers de guerre (1914-1919). Paris.

Cegielski J. \& D. McMurray. 2004. 'The relationship between malnutrition and tuberculosis : evidence from studies in humans and experimental animals', International Journal of Tuberculosis and Lung Disease, 8 (2004), pp. 286-298.

'Chronique'. 1919 in Revue internationale de la Croix-Rouge et Bulletin international des Sociétés de la Croix-Rouge, 1 (1919), pp. 37-58.

Comité International du Croix Rouge. 1915a. Rapports de MM. Ed. Navilled V. Van Berchem, Dr. C. De Marval - A. Eugster, sur leurs visits aux camps de prisonniers en Angleterre, France et Allemagne. Geneva.

Comité International du Croix Rouge. 1915b. Rapports de MM. Dr. C. De Marval, A. Eugster, sur leurs visits aux camps de prisonniers en France et en Allemagne. Geneva.

Denda, D. 2015. 'Srpski ratni zarobljenici u Velikom ratu' in Prvi svetski rat, Srbija, Balkan i velike sile, ed. by Srdjan Rudić and Miljan Milkić. Beograd, pp. 17-37.

Doegen, W. 1921. Kriegsgefangene Völker, Band I : Der Kriegsgefangenen Haltung und Schicksal in Deutschland. Berlin.

Dowling, T. 2005. 'Austria-Hungary, Home Front' in World War I : Encyclopedia, ed. by Spencer C. Tucker, 5 vols. Santa Barbara, I, pp. 259-260. 
Fischer, E., B. Widmann \& J. Bell. 1927. Das Werk des Untersuchungsausschusses der Verfassunggebenden Deutschen Nationalversammlung und des Deutschen Reichstags, 4 vols. Berlin, III-1 'Verletzungen des Kriegsgefangenenrechts'.

Fogelquist, A. 2011. Politics and Economic Policy in Yugoslavia, 1918-1929. Morrisville.

Gross, G. 2006. Die vergessene Front - der Osten 1914/15 : Ereignis, Wirkung, Nachwirkung. Paderborn.

Habert, H. 1919. Binnen het prikkeldraad : naar verhalen van uitgeweken Serviërs. Amsterdam.

Herwig, H. 2014. The First World War : Germany and Austria-Hungary 1914-1918. London.

Hinz, U. 2005. Gefangen im Großen Krieg : Kriegsgefangenschaft in Deutschland 19141921. Essen.

Hoffman, C. 1920. In the prison camps of Germany; a narrative of " $Y$ " service among prisoners of war. New York.

Ilić-Marković, G. (ed.) 2014. Veliki rat - Der große Krieg : Der Erste Weltkrieg im Spiegel der serbischen Literatur und Presse. Vienna.

Jones, H. 2009. 'A Missing Paradigm? Military Captivity and the Prisoner of War, 1914-18' in: Captivity, forced labour and forced migration in Europe during the First World War, ed. by Matthew Stibbe. London.

Kramer, A. 2008. Dynamic of Destruction : Culture and Mass Killing in the First World War. Oxford.

Laffan, R. 1918. The Guardians of the Gate : Historical Lectures on the Serbs. Oxford.

Leclercq, T. 1924. Het Informatiebureau van het Nederlandsche Roode Kruis : en zijne werkzaamheden in verband met den oorlog 1914-1918. The Hague.

Lith, H. van. 2011. Twee miljoen pakketten : over internationaal liefdewerk. Soesterberg.

Lukić, N. 2017. Interniranje stanovništva i vojnika Kraljevine Srbije u austrougarske logore tokom Prvog svetskog rata: popisi umrlih u logoru Boldogasonj / Frauenkirhen 1914-1918. Belgrade.

McCarthy, D. 1918. The prisoner of war in Germany; the care and treatment of the prisoner of war with a history of the development of the principle of neutral inspection and control. New York.

Milanović, J. 2015. 'Uloga porodice Grujić u Velikom ratu' in: Srbi i Prvi svetski rat 1914-1918: zbornik radova sa međunarodnog naučnog skupa održanog 13-15. juna 2014, ed. by Dragoljub Živojinović. Beograd, pp. 555-568.

Milojević, M. 1994. Balkanska ravnoteža : sećanja kraljevog diplomate. Belgrade.

Mitrović, A. 2014. Srbija u Prvom svetskom ratu. Beograd.

Nachtigal, R. 2008. 'Zur Anzahl der Kriegsgefangenen im Ersten Weltkrieg' in: Militärgeschichtliche Zeitschrift 67-2 (2008), pp. 345-384. 
Office d'information des oeuvres de secours aux prisonniers de guerre. 1916. 'Envois de l'Oeuvre Internationale pour Blessès et Prisonniers : Comité de La Haye' in: Bulletin de l' Office d'information, 28 (1916), pp. 368-369.

Otte, K. 1999. Lager Soltau: Das Kriegsgefangenen- und Interniertenlager des Ersten Weltkriegs (1914-1921): Geschichte und Geschichten. Soltau.

Otto, A. 2008. '»...wie ich mit der Vergangenheit brach«. Kriegserfahrungen und Erinnerungswege des russischen Offiziers Georgij Benua (1914-1920/1966)' in: Militärgeschichtliche Zeitschrift 67-2 (2008), pp. 409-449.

Overmans, R. 2003. 'Kriegsverluste' in: Enzyklopädie Erster Weltkrieg, ed. by Gerhard Hirschfeld and others. Paderborn, pp. 663-666.

Procacci, G. 2006. '»Fahnenflüchtige jenseits der Alpen«. Die italienischen Kriegsgefangenen in Österreich-Ungarn und Deutschland' in: Kriegsgefangene im Europa des Ersten Weltkriegs, ed. by Jochen Oltmer. Paderborn, pp. 194-215.

Rachamimov, A. 2002. POWs and the Great War: Captivity on the Eastern Front. Oxford.

Radovanović, M. 2017. Holandsko "Milosrde" i Srbi u Velikom ratu (1916-1918) : Nemi svedoci. Belgrade.

Rapport sur les dommages de guerre causés à la Serbie et au Monténégro présenté à la Commission des réparations des dommages. 1919. Paris.

Rawe, K. 2005. “...wir werden die schon zur Arbeit bringen!”. Essen.

Reiss, A. 1919. Le traitement des prisonniers et des blessés par les Germano-Bulgares: résultats de l'enquête exécutée sur le front de Salonique. Paris.

Ristić, D. 2016. 'Bolno nasleđe : Srpski ratni internirci na tlu Holandije tokom i neposredno posle Prvog svetskog rata' in: Istorijske sveske, 32 (2016), pp. 14-19.

Serbian Hospitals Fund and Other Special War Relief Contributions for Serbia. 1917. New York.

Serbian Section of the Bureau of Relief to Prisoners of War. 1917. The Other Side of the Trenches. Berne.

Speed, R. 1990. Prisoners, Diplomats, and the Great War: A Study in the Diplomacy of Captivity. New York.

Spoerer, M. 2006. 'The Mortality of Allied Prisoners of War and Belgian Civilian Deportees in German Custody during the First World War : A Reappraisal of the Effects of Forced Labour' in: Population Studies, 60-2 (2006), pp. 121-136.

Stefanović, D. 1926. 'Gubitci saveznika u svetskomratu 1914-1918. Godine’ in: Ratnik, 42-11 (1926), pp. 117-132.

Stienen, J. 2016 'Rotterdam, een veilige haven voor vluchtelingen', in: Rotterdam en de Eerste Wereldoorlog, ed. by Henk van der Linden. Soesterberg, pp. 333-354. 
Stojančević, V. 1988. Srbija i srpski narod za vreme rata i okupacije 1914-1918. Godine. Leskovac.

Topalović, Ž. 1918. Za naše zarobljenike. Corfu.

Vemić, M. 2014. 'Pomor Srba ratnih zarobljenika i interniranih civila u austrougarskim logorima za vreme Prvog svetskog rata 1914-1918' in: Zbornik Matice srpske za društvene nauke, 147/2, (2014), pp. 201-234.

Vendrig, T., F. Vendrig \& J. Stienen. 2016. Serbian Soldiers of World War I Who Died in the Netherlands. Belgrade.

Weiland, H. (ed.) 1931. In Feindeshand : Die Gefangenschaft im Weltkriege in Einzeldarstellungen, 2 vols. Vienna.

Zatková, J. 2013. Zabudnutí vojaci : Zajatci v oblasti Vojenského velitel'stva Bratislava 1914 - 1918. Bratislava.

Zürcher, K., M. Zwahlen, M. Ballif, et al. 2016. 'Influenza Pandemics and Tuberculosis Mortality in 1889 and 1918 : Analysis of Historical Data from Switzerland' in: PLoS ONE, 11/10 (2016).

\section{Internet sources}

www1

Government of Serbia. 2009. Počela primena srpsko-slovačkog sporazuma o zaštiti vojnih memorijala $i$ mesta stradanja. Visited on 8 January 2018 at http://www. srbija.gov.rs/vesti/vest.php?id=115868

www2

Ilić-Marković, G. 2015. Totenbuch (Militärfriedhof Mauthausen) ÖSK. Visited on 8 January 2018 at http://www.pows-ww1.at/projekt/totenbuecher

www3

Langthaler, E. 2016. 'Food and Nutrition (Austria-Hungary)' in: 1914-1918-online : International Encyclopedia of the First World War, ed. by Ute Daniel and others, issued by Freie Universität Berlin. Visited on 8 January 2018 at https:// encyclopedia.1914-1918-online.net/article/food_and_nutrition_austria-hungary 